\title{
Hernia de Amyand Amyand's hernia
}

\author{
Marcelo Güemes (D), Eduardo Rodríguez (D), Gastón Ferreira
}

\footnotetext{
Servicio de Cirugía General, Hospital Padre
Ángel Buodo, Angel Buodo,
General Acha, La Pampa, Argentina.

Los autores declaran no tener conflictos de interés.

Conflicts of interest None declared.

Correspondencia Correspondence: Marcelo Güemes E-mail: marceloguemes@ hotmail.com
}

Recibido | Received 05-03-19

Aceptado | Accepted 21-05-19

\begin{abstract}
RESUMEN
La presencia del apéndice cecal en el saco de una hernia inguinal se denomina hernia de Amyand ${ }^{1,2}$ Su incidencia varía -según distintos autores- del 0,13\% al 1,7\%. Es una rara patología que se diagnostica intraoperatoriamente, ya que su diagnóstico preoperatorio es excepcional. No obstante, en citas bibliográficas se han descripto pocos casos de diagnóstico intraoperatorio, por lo que es importante tener la sospecha clínica en hernias incarceradas de cara al diagnóstico diferencial y a valorar la solicitud de estudios diagnóstico. Su tratamiento es la apendicectomía o reducción del apéndice cecal a la cavidad abdominal asociada a herniorrafia o hernioplastia ${ }^{3}$.
\end{abstract}

Palabras clave: apendicitis aguda, hernia de Amyand

\section{ABSTRACT}

Amyand's hernia is defined as an inguinal hernia containing the vermiform appendix ${ }^{1,2}$. This rare condition, with an incidence between $0.13 \%$ and $1.7 \%$, is diagnosed during surgery, as the preoperative diagnosis is exceptional. Few cases of intraoperative diagnosis have been described in the literature. The diagnosis should be suspected in cases of incarcerated hernias so as to order the specific tests. The surgical management includes appendectomy or appendix reduction to the abdominal cavity associated to mesh repair or primary hernia repair without mesh ${ }^{3}$.

Keywords:Amyand hernia, appendicitis.

ID ORCID: Marcelo R. Güemes, 0000-0002-8841-881X; Eduardo H. Rodríguez, 0000-0002-6395-4157
La mayoría de los autores ${ }^{1,2,4-6}$ definen la hernia de Amyand como la presencia del apéndice cecal en el interior del saco de una hernia inguinal, y la hernia de Garengoet cuando el apéndice se ubica en un saco herniario crural. Sin embargo, algunos definen la primera ante la presencia de inflamación (apendicitis) y no solo la protrusión del órgano ${ }^{4}$.

La escasa incidencia, $0,13 \%^{6}$ a $1,7 \%^{5}$, y la bibliografía al respecto determinan un bajo índice de sospecha preoperatorio ${ }^{2}$; habitualmente la indicación quirúrgica es una hernia inguinal complicada. A su vez, hay falta de consenso en el tratamiento de la hernia y el apéndice, específicamente con respecto a la indicación de realizar la apendicectomía cuando esta no muestra signos de inflamación, y con respecto a colocar malla protésica en la reparación inguinal cuando se realizó la apendicectomía, debido al riesgo de contaminación de la malla ${ }^{1,4-6}$.

Paciente masculino de 56 años que se presenta por guardia con dolor abdominal, de 24 horas de evolución, tipo cólico, asociado a vómitos, distensión abdominal y falta de eliminación de gases. Entre sus antecedentes se destacan el tabaquismo, hipertensión arterial y dislipidemia. Al examen físico presenta un abdomen distendido, con RHA negativos, doloroso a la palpación generalizada, sin defensa y sin peritonismo, timpánico a la percusión. Se constata una hernia inguinal derecha atascada. Se procede a realizar laboratorio (se encuentra leucocitosis con desviación de la fórmula hacia la izquierda), radiografías y valoración clínica prequirúrgica.

El paciente es intervenido quirúrgicamente, por un abordaje anterior; se observa el apéndice cecal y parte del ciego dentro del saco herniario (Fig. 1). Se decide reintroducir el contenido en la cavidad abdominal sin realizar una apendicectomía debido a la ausencia de inflamación y para evitar una contaminación de la malla durante la hernioplastia.

Se procede a reparar la pared inguinal con una técnica tipo Lichtenstein (Fig. 2) con muy buena evolución posoperatoria.

La sintomatología típica de la hernia de Am- 


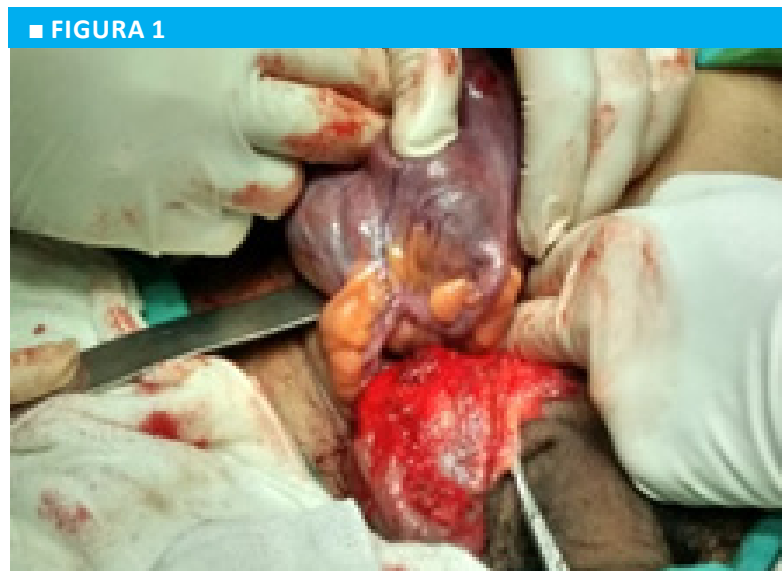

Contenido del saco herniario donde se observa ciego y apéndice cecal, sin signos de inflamación

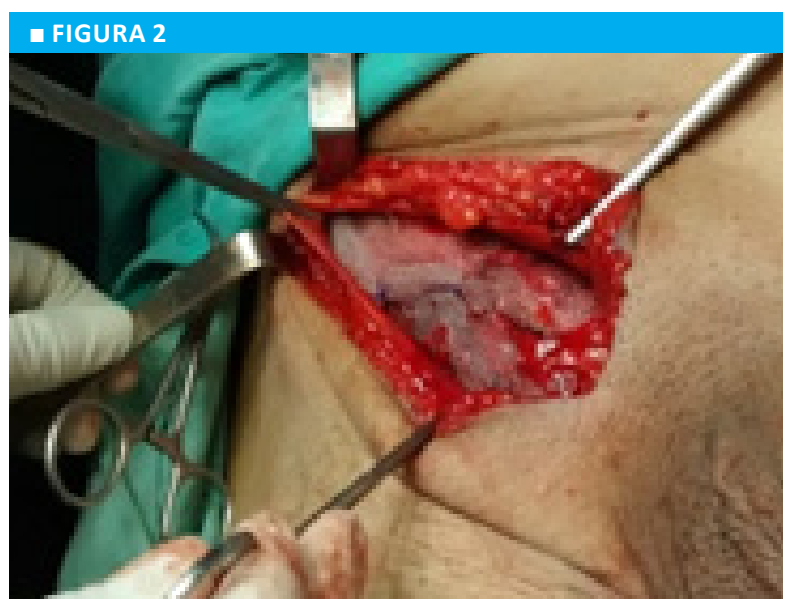

Hernioplastia y colocación de malla de polipropileno, técnica de Lichtenstein yand es el dolor en FID asociado a una hernia inguinal derecha complicada ${ }^{1,2,5,6}$; sin embargo, el índice de sospecha preoperatorio es muy bajo, debido a la baja incidencia de este cuadro, 0,13-1,7\% ${ }^{5,6}$; a su vez, el índice de apendicitis en el saco herniario es aún menor, del $0,07 \%$ al $0,13 \%{ }^{5}$. Sin lugar a dudas, la realización de una TC abdominal y/o ecografía abdominal, permite en algunos casos alcanzar un diagnóstico preoperatorio ${ }^{2}$.

Debido a la escasa frecuencia del cuadro, carecemos de series que muestren el manejo adecuado de esta patología ${ }^{2}$, ya que algunos autores argumentan la apendicectomía según el estado de dicho órgano y otros la realizan en todos los casos independientemente de que el apéndice esté inflamado o no.

Por lo que respecta a la reparación herniaria, el procedimiento de referencia (gold standard) es la utilización de mallas, con lo cual disminuiría la tasa de recidiva de dicha patología, pero su uso estaría contraindicado en cirugías contaminadas.

Respecto del tratamiento, nos guiamos por la clasificación de Losanoff y Bason ${ }^{3}$ (Tabla 1 ):

\begin{tabular}{|c|c|c|}
\hline \multicolumn{3}{|c|}{ TABLA 1} \\
\hline \multicolumn{3}{|c|}{ Clasificación de Losanoff y Basson ${ }^{3}$} \\
\hline Tipo 1 & Con apéndice normal & $\begin{array}{l}\text { Reducción del apéndice y } \\
\text { hernioplastia }\end{array}$ \\
\hline Tipo 2 & $\begin{array}{c}\text { Con apendicitis aguda } \\
\text { en el saco }\end{array}$ & $\begin{array}{l}\text { Apendicectomía y } \\
\text { herniorrafia }\end{array}$ \\
\hline Tipo 3 & Apendicitis aguda y peritonitis & $\begin{array}{l}\text { Apendicectomía vía } \\
\text { abdominal y herniorrafia }\end{array}$ \\
\hline Tipo 4 & $\begin{array}{c}\text { Apendicitis aguda y otra pato- } \\
\text { logía asociada (adenocarcino- } \\
\text { ma, mucocele, etc.) }\end{array}$ & $\begin{array}{l}\text { Apendicectomía, herniorrafia } \\
\text { y tratamiento de la patología } \\
\text { asociada }\end{array}$ \\
\hline
\end{tabular}

Most authors ${ }^{1,2,4-6}$ define Amyand's hernia as an inguinal hernia containing the vermiform appendix and De Garengeot's hernia as the presence of the appendix within a femoral hernia sac. Yet, some authors require the presence of inflammation (acute appendicitis) in the hernia sac to define Amyand's hernia4.

The low incidence of this condition, between $0.13 \%{ }^{6}$ and $1.7 \%^{5}$, and the scarce bibliography available determine that this condition is rarely diagnosed before surgery ${ }^{2}$, which is generally indicated in case of a complicated inguinal hernia. There is no agreement about how to treat the hernia and the appendix, specifically in the indication of appendectomy when the appendix shows no signs of inflammation or in the need for mesh hernia repair during appendectomy due to the risk of mesh infection ${ }^{1,4-6}$.

A 56-year-old male patient presented in the emergency department with abdominal cramping lasting 24 hours associated to vomiting, abdominal bloating and inability to pass gas. He had a history of smo- king habits, hypertension and dyslipidemia. On physical examination, the abdomen was distended and tender but with no rigidity or rebound tenderness, was tympanic and with absence of bowel sounds. An incarcerated right inguinal hernia was detected. The patient underwent laboratory tests which showed leukocytosis with granulocyte predominance, radiographies and preoperative risk assessment,

The patient and was operated on via and anterior approach. The vermiform appendix was observed in the hernia sac (Fig. 1). The content was introduced in the abdomen but the appendix was not resected due to the absence of inflammation and to prevent contamination of the mesh during hernia repair.

The inguinal wall was repaired with the Lichtenstein technique (Fig. 2) with favorable postoperative outcome.

Pain in the right inguinal region associated to a complicated right inguinal hernia is the typical symptom of Amyand's hernia ${ }^{1,2,5,6}$. Yet, the diagnosis is not 


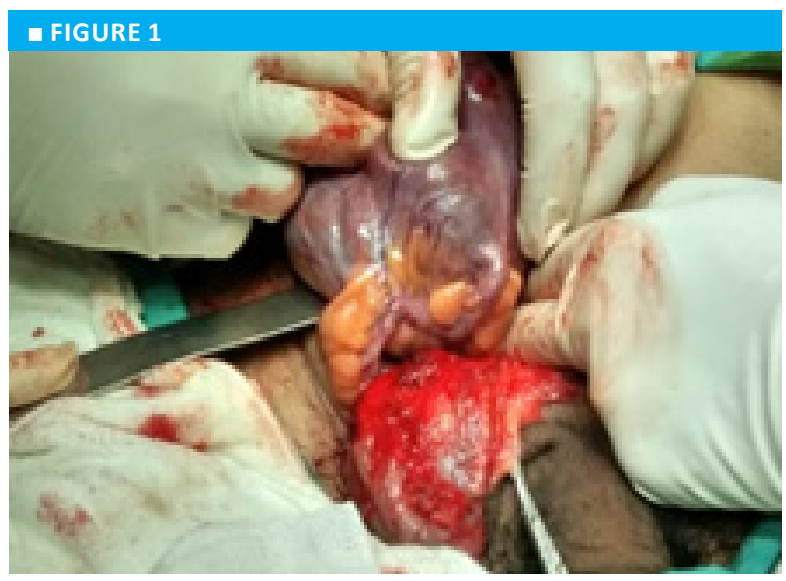

Hernia sac containing the cecum and vermiform appendix.

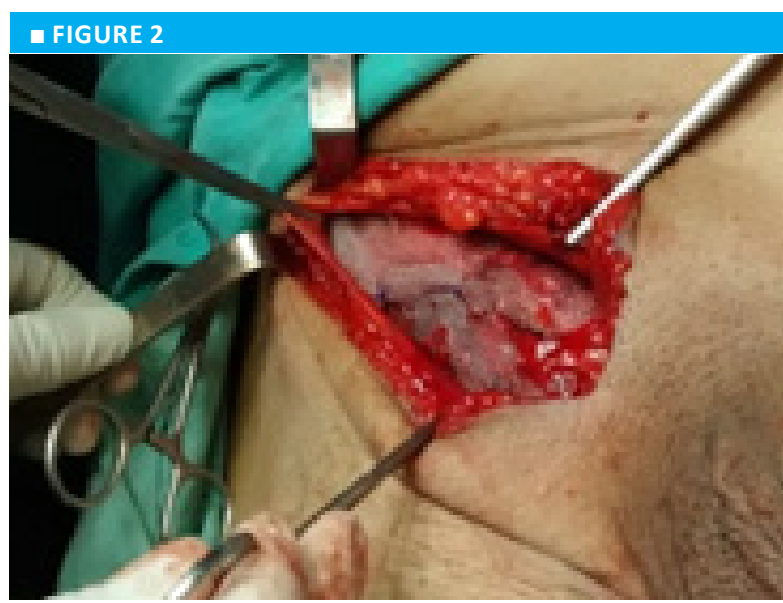

. Hernia repair and placement of a polypropylene mesh with the Lichtenstein technique.

often made due to the low incidence of this condition, between 0.13 and $1.7 \%^{5,6}$ and because appendicitis in the hernia sac is even more rare, with an incidence between $0.07 \%$ and $0.13 \%{ }^{5}$. The preoperative diagnosis is made by computed tomography scan of the abdomen or abdominal ultrasound ${ }^{2}$.

There no agreement about the adequate management of Amyand's hernia due to the low prevalence of this condition2. While some authors recommend appendectomy in cases of inflammation, others always resect the appendix, even in the absence of inflammation.

Mesh hernia repair is the gold standard procedure to reduce the rate of recurrence, but is contraindicated in contaminated surgeries.

We use the Losanoff and Basson's classification $^{3}$ to guide treatment (Table 1 ):

\section{- TABLE 1}

Losanoff and Basson's classification

Type 1 Normal appendix

Type 2

Acute appendicitis within an inguinal hernia

Type 3 Acute apendicitis and peritonitis

Acute appendicitis and other

Type 4 related condition (adenocarcinoma or mucocele, among others)
Hernia reduction, mesh repair

Appendectomy, primary repair of hernia, no mesh

Laparotomy appendectomy, primary repair of hernia, no mesh

Laparotomy appendectomy, primary repair of hernia, no mesh and treatment of the associated condition
1. Aranda A, Rojas R, López L, Correa M, Sánchez R, Soskin R. Apéndice cecal en el saco herniario: Hernia de Garengeot vs Hernia de Amyand. Presentación de casos clínicos. An FacCienc. Méd; 2009;XLII:1-4.

2. Agirre LE, Prieto MC, García AE, García MJ, Sarriugarte A, Colina A Hernia de Amyand (tipo 2 de Losanoff) diagnosticada preoperatoriamente y tratada mediante hernioplastia con malla biológica. Rev Hispanoam Hernia. 2014; 2(4):169-72.

3. Ferreira G. Historia de la apendicitis aguda. En su: Apendicitis aguda, nuevo método diagnóstico. Córdoba: Tinta libre Ediciones;
2016. pp 13-7.

4. Losanoff JE, Basson M.: Amyand hernia: A classification to improve management. Hernia. 2008; 12:6-325.

5. Muriel JS, Torregrosa A, García P, López M, Argüelles B, Lledó JA. Hernia de Amyand: presentación de tres casos y revisión bibliográfica. Rev Hispanoam. 2016; 4:107-11.

6. Nicola M, Mora G, Stock R, Vallejos R, Robles M, Tapia C y col. Hernia de Amyand: presentación de un caso y revisión de la literatura. Rev Chilena de Cirugía. 2006; 59:142-4. 